Acta Universitatis Wratislaviensis • No 3982

Literatura i Kultura Popularna XXV, Wrocław 2019

https://doi.org/10.19195/0867-7441.25.19

\author{
Adam Mazurkiewicz \\ ORCID: 0000-0003-3804-6445 \\ Uniwersytet Łódzki
}

\title{
Modny „pan władza”. O strojach funkcjonariuszy MO w polskiej powieści milicyjnej lat 1956-1989
}

Slowa kluczowe: MO, powieść kryminalna, garnitur, mundur, dress code

Keywords: MO, crime fiction, suit, uniform, dress code

Rodzima powieść milicyjna to zjawisko w literaturze kryminalnej tyleż rzadkie, co ściśle związane z systemem politycznym lat 1944-1989. Pozostając na usługach ideologów, jej twórcy dążyli do ukazania rzeczywistości zgodnie z tendencjami wyznaczonymi przez aktualny kurs partii. Relacja ta była tym istotniejsza, że w propagandzie lat 1945-1989 funkcjonariusze Milicji Obywatelskiej reprezentowali jedyne siły porządkowe, podczas gdy de facto aparat bezpieczeństwa publicznego był - co podkreśla Daniel Piotrowski — organem bezpieczeństwa państwa (formalnie był to zakres działania Służby Bezpieczeństwa powstałej w 1956 roku w wyniku reorganizacji Ministerstwa Bezpieczeństwa Publicznego). $\mathrm{Z}$ tego względu na wizerunku MO (a zatem i jej pracowników) negatywnie odcisnęło się piętno współpracy z „bezpieką” postrzeganą jako siły represyjne ${ }^{1}$. Tym

1 Zob. D. Piotrowski, Struktura organizacyjna Policji po 1989 r., „Security, Economy \& Law” 2015, nr 7, s. 49; P. Majer, Zacieśnianie więzów. Milicja Obywatelska a aparat bezpieczeństwa w latach 1944-1949, [w:] System represji stalinowskich w Polsce 1944-1956. Represje w Marynarce Wojennej, red. I. Hałagida, Gdańsk 2003, s. 31-44; idem, Milicja Obywatelska w systemie organów władzy PRL, Torun 2003, s. 62-73 (tu również: rozkaz nr 13 Stanisława Radkiewicza z dnia 18 marca 1949 roku o zespoleniu działań Milicji Obywatelskiej z pracą aparatu bezpieczeństwa, s. 216219); idem, Milicja Obywatelska 1944-1957, Olsztyn 2004, s. 381-383; idem, Milicyjna agentura 1944-1957, „Dzieje Najnowsze” 2005, nr 1, s. 47-68. Takie utożsamienie sfer zainteresowań obu służb wynikało z początków ich działalności w powojennej Polsce; zob. Ł. Bojko, Geneza i działalność Resortu Bezpieczeństwa i Urzędu Bezpieczeństwa Polski Ludowej w latach 1944-1945, [w:] 
zapewne należy tłumaczyć abominację jednego z autorów zatrzymanego przez cenzurę listu, będącego świadkiem wydarzeń w Golędzinowie 5 października 1957 roku, charakteryzującego funkcjonariuszy sił porządkowych w następujący sposób: „zezwierzęcone twarze, typowe zbiry”2.

Świadomość negatywnego nastawienia społeczeństwa wobec sił porządkowych sprawiła, że decydenci starali się „ocieplić” wizerunek MO, kreując jej funkcjonariuszy na „bohaterów zbiorowej wyobraźni”. Co więcej, milicjant w funkcji pozytywnego protagonisty miał być kontrpropozycją wobec pojawiających się coraz częściej po roku 1956 przekładów zachodniej literatury masowej, w tym powieści z nurtu „czarnego kryminału” reprezentowanych głównie przez utwory Raymonda Chandlera i Dashiella Hammetta ${ }^{3}$. Opowieści te - podobnie jak nieliczne przekrojowe szkice, poświęcone zachodniemu kryminałowi — odczytywane były przez ówczesną krytykę literacką jako świadectwo upadku obyczajów w społeczeństwie kapitalistycznym (przypomnijmy, iż — zwłaszcza w twórczości Chandlera — policja pozostawała na usługach organizacji przestępczych, legitymizując sobą bezprawne działania) ${ }^{4}$. Tym samym implicite kryminalna powieść socjalistyczna funkcjonowała nie tylko jako literatura rozrywkowa, spełniała bowiem zarazem wymogi stawiane przez ideologów przed sztuką utożsamianą z przekazem propagandowym. $\mathrm{Z}$ tego względu zabiegi propagandowe, mające na celu ukazywanie funkcjonariuszy MO w jednoznacznie pozytywny sposób, pośrednio „wybielały” też inne służby resortowe; niekiedy zresztą, jak w powieści Tadeusza Kosteckiego Zaułek mroków (1956), pozytywnym zbiorowym bohaterem był Urząd Bezpieczeństwa, pracownicy MO zaś odgrywali rolę poślednią fabularnie. Wynikało to z prób rehabilitacji resortu w obliczu przemian związanych z odejściem w życiu społeczno-politycznym i kulturalnym od dogmatycznej wersji stalinizmu i obserwowanym od roku 1955 „pękaniem lodów” (określenie Józefa Kelery ${ }^{5}$ ), którego apogeum przypadło — w myśl historycznoliterackiego stereotypu — na Październik '56.

Skonwencjonalizowanie rozwiązań i postaci przyczyniło się do ukształtowania stereotypów w obrazowaniu zarówno pozytywnych, jak i negatywnych bohaterów. O ile jednak zbrodniarzy najczęściej traktowano na kartach literatury jako

„Polska Ludowa” 1944-1989 - wybrane problemy historii politycznej i społecznej, red. D. Litwin-Lewandowska, K. Bałękowski, Lublin 2016, s. 17-36.

2 Za: K. Rokicki, Chrzest bojowy ZOMO, „Pamięć i Sprawiedliwość” 2007, nr 6/1 (11), s. 421. W innym cytowanym przez badacza liście czytamy równie niepochlebną opinię, podsumowaną słowami: ,zaślinione mordy” (ibidem).

${ }^{3} \mathrm{Na}$ temat różnic między zachodnią i socjalistyczną literaturą kryminalną zob. J. Siewierski, Powieść kryminalna, Warszawa 1979, s. 132-136.

4 Zob. np. T. Bielicki, Kto zabit Ritę Croy?, „Dziś i Jutro. Katolicki tygodnik społeczny” 1954, nr 37, s. 8; B. Surówka, Maty przegląd „,kryminalistyczny”, „Panorama” 1956, nr 36, s. 12-13; M. Zakrzewski, Trucizna, sztylet, kula, „Życie Literackie” 1956, nr 9, s. 7; Ster, Powieść kryminalna i małpie zwierciadło, „Słowo Powszechne” 1957, nr 178, s. 4.

5 Zob. J. Kelera, Odwilż w dramacie 1954-1956, „Dialog” 1989, nr 6, s. 99. 
postacie będące bardziej typami niż charakterami, o tyle w wypadku bohaterów pozytywnych można zauważyć tendencję do niuansowania kreacji artystycznej.

Szczególne miejsce pośród bohaterów zajmuje milicjant będący przedstawicielem porządku społecznego. To on — wraz z instytucją, którą reprezentuje - jest osią fabularną opowieści, nawet jeśli nie jest bohaterem pierwszoplanowym. Dzieje się tak, albowiem — zgodnie z quasi-genologicznym charakterem określenia przynależności gatunkowej — w utworach współtworzących nurt ,powieści milicyjnej” istotna jest nie tyle zbrodnia (a nawet procedury prowadzące do wykrycia jej sprawcy), ile obraz omnipotencji organów ścigania i kolektywny charakter ich pracy. Zatem z perspektywy retorycznej można dostrzec w takim utożsamieniu zabieg o charakterze pars pro toto: pojedynczy funkcjonariusz staje się reprezentantem resortu ${ }^{6}$. Tym samym — jak pisze Krzysztof Mudyń najbardziej rozpoznawalna część świata przedstawionego, jakim (w rozumieniu strukturalistycznym) pozostaje bohater protagonista, staje się metaforą całości, to jest służb resortowych, pełniąc zarazem funkcję modelu ich działania ${ }^{7}$. Zależność tę oddają słowa z jednej z powieści Jerzego Egigeya (właśc. Jerzego Koryckiego):

W walce pomiędzy pojedynczym przestępcą lub nawet najlepiej zorganizowanym gangiem a aparatem sprawiedliwości istnieje ogromna przewaga państwa. Prędzej czy później sprawiedliwość zawsze dosięgnie zbrodniarza ${ }^{8}$.

Z tego względu wygląd jednostki pozostaje sfunkcjonalizowany: milicjant ma bowiem nie tylko reprezentować władzę, ale też model urody, korespondujący z walorami moralnymi i etycznymi bohatera ${ }^{9}$. Z kolei akcentowana w utworach literackich ogłada towarzyska milicjantów zdaje się korespondować z opracowaniem autorstwa Ireny Gumowskiej i Jana Kapicy Uprzejmy milicjant (1964), stworzonym we współpracy z Oddziałem Szkolenia Komendy Głównej MO, w którym podkreślano funkcjonowanie służb porządkowych w obrębie społeczeństwa:

${ }^{6}$ Zob. J. Jastrzębski, „Ewa wzywa 07”- 07 nie odpowiada, [w:] idem, Czas relaksu. O literaturze masowej i jej okolicach, Wrocław 1982, s. 192.

7 Na temat mechanizmu metaforyzowania rzeczywistości w zasadzie pars pro toto zob. K. Mudyń, O dwóch sposobach metaforyzacji świata. Pars pro toto czy intra pro extra?, „Albo Albo” 2008, nr 1 , s. 108 .

8 J. Edigey, Testament samobójcy, Warszawa 1972, s. 181. Deklaracja ta jest tym istotniejsza dla odczytania przywołanego tu utworu, że zarówno Edigey, jak i na przykład Zygmunt Zeydler-Zborowski, odwoływali się w utworach do raportów milicyjnych, dotyczących autentycznych zbrodni.

${ }^{9}$ Pewnym tropem interpretacyjnym umożliwiającym konceptualizację funkcji zabiegu pars pro toto w perspektywie ideologicznej, charakteryzującej powieść milicyjną, są słowa Romana Jacobsona intencjonalnie odnoszące się do retoryki filmowej: „Pars pro toto jest podstawową metodą filmowej przemiany rzeczy w znaki" (idem, Upadek filmu?, przeł. C. Dondziłło, [w:] Estetyka i film, red. A. Helman, Warszawa 1972, s. 94). Per analogiam w „powieści milicyjnej” obserwujemy przemianę jednostkowego bohatera (Jacobsonowskiej „,rzeczy”) w „znak”, to jest reprezentację organów ścigania. 
Milicja nie jest [...] i nie może być wyizolowana ze społeczeństwa. Dlatego też o kulturze milicjanta można mówić tylko na tle kultury wszystkich obywateli. Upraszczając to zagadnienie, można powiedzieć, że kultura milicji nie jest inna niż ta, która cechuje ogół społeczeństwa ${ }^{10}$.

Funkcjonariusz MO pojawia się zatem na kartach powieści milicyjnej nie jako literacki „,charakter”, lecz raczej „typ normotwórczy” — nosiciel pożądanych społecznie cech, współbrzmiących zarazem z propagandowym obrazem formacji państwowej, w której pracowa ${ }^{11}$.

Można przy tym dostrzec $\mathrm{w}$ powieści milicyjnej dwie strategie realizacji naszkicowanych tu założeń:

- taką kreację protagonisty, w której podkreślony byłby wzorcotwórczy charakter wyglądu zewnętrznego i dbałość o jego reprezentacyjność;

— stworzenie image'u ,równiachy”/,swojaka”, z którym mógłby identyfikować się modelowy czytelnik.

Zarysowana typologia odwołuje się do rozróżnienia dokonanego przez Stanisława Barańczaka, według którego w rodzimej powieści kryminalnej (nie tylko nurcie milicyjnym, jakkolwiek intencjonalnie o nim Barańczak pisze) można rozróżnić dwa opozycyjne warianty pozytywnego bohatera: światowca erudyty oraz przeciętnego człowieka, który pozornie nie wyróżnia się niczym szczególnym. Tym samym — konstatuje Barańczak — kreacja polskiego detektywa funkcjonuje pomiędzy modelem stworzonym przez Iana Fleminga na potrzeby cyklu powieści o superagencie Jamesie Bondzie i inspektorem Jules'em Maigretem — protagonistą utworów George'a Simenona ${ }^{12}$. Niewątpliwie też Barańczak ma rację, pisząc o inspirowanych myślą Edgara Morina mechanizmach projekcji i identyfikacji jako zasadach kreacji bohatera powieści kryminalnej ${ }^{13}$ : ten pierwszy wykorzystywany jest w kreacji wzorcotwórczej jako punkt odniesienia aspiracji czytelnika, pragnącego naśladować zaproponowany mu wzorzec; drugi umożliwia odbiorcy mentalne odnalezienie siebie w kreacji artystycznej.

Dalej zaprezentujemy oba rozwiązania. Już teraz zaznaczmy jednak, że mogą pojawiać się one jako komplementarne w jednym utworze; mamy wówczas do czynienia z sytuacją, gdy — niczym w powieściach Akcja „Chirurg” (1968) Barbary Nawrockiej-Dońskiej i Ryszarda Dońskiego oraz Artura Moreny (właśc. Andrzeja Wydrzyńskiego) Czas zatrzymuje się dla umarłych (1969), powieściach różnych

10 I. Gumowska, J. Kapica, Uprzejmy milicjant, Warszawa 1964, s. 3 . Był to numerowany druk tajny o charakterze instrukcji, funkcjonujący w obiegu wewnętrznym. Dostęp do niego mogli mieć jedynie ci twórcy powieści milicyjnej, którzy — niczym Helena Sekuła — byli pracownikami resortowymi.

11 Osobną kwestią pozostaje moda w nurcie literatury kryminalnej komplementarnym wobec powieści milicyjnej, jakim w latach 1956-1989 był kryminał pseudozachodni (jest on charakterystyczny dla prozy Joe Alexa (właśc. Macieja Słomczyńskiego). W tym wypadku moda wzorowana była na uogólnionych wyobrażeniach stroju angielskiego dżentelmena.

12 Zob. S. Barańczak, Poetyka polskiej powieści kryminalnej, „Teksty” 1973, nr 6, s. 70.

13 Zob. ibidem, s. 69. 
autorów tworzących cykl utworów o przygodach Borewicza - pojawia się inspirowany klasyczną literaturą kryminalną zespół złożony z przenikliwego, modnie ubranego śledczego (jego kreacja wzorowana jest na Sherlocku Holmesie) oraz funkcjonariusza odgrywającego na planie fabularnym rolę pomocnika (analogiczną do funkcji Watsona), który nie wyróżnia się powierzchownością i pozostaje tłem działań protagonisty (taką rolę odgrywa początkowo Zubek, później Jaszczuk) ${ }^{14}$.

Inną cechą stroju bohaterów powieści milicyjnej — niezależnie od obranej strategii artystycznej - jest traktowanie garnituru jako substytutu ubrania codziennego; w ten sposób strój ten staje się w godzinach pracy bohaterów reprezentacją munduru ${ }^{15}$. Taką zamianę można thumaczyć charakterem ich pracy w pionie dochodzeniowo-śledczym ${ }^{16}$. Mimo to interesujące wydaje się, że sam mundur nie pojawia się nazbyt często na kartach powieści milicyjnych jako strój służbowy. Dzieje się tak mimo istnienia stosownych, dotyczących go regulacji prawnych, dookreślających nie tylko krój ubrania służbowego, ale i takiego, które milicjant

$14 \mathrm{O}$ innych funkcjach zestawienia protagonisty i jego pomocnika zob. R. Dudziński, Między literatura a filmem, między władza a widzem. Miejsce ideologii w serialu „,07 zgłoś się” i jego literackich pierwowzorach, [w:] Wybory popkultury. Relacje kultury popularnej z polityka, ideologia i spoleczeństwem, red. K. Kowalczyk, J. Płoszaj, Wrocław 2014, s. 91.

15 Sam wybór garnituru nacechowany jest również wartościująco. To — w myśl uwagi Cally Blackmana - „podstawowa pozycja w garderobie każdego modnego mężczyzny” (idem, 100 lat mody męskiej, przeł. Ewa Romkowska, Warszawa 2015, s. 5).

${ }^{16}$ Co więcej, niekiedy pojawia się sugestia specjalnego doboru stroju w trakcie wykonywania czynności służbowych, tak aby mógł być wykorzystywany jako kamuflaż; w Zaułku mroków (Warszawa 1956) Tadeusza Kosteckiego czytamy: „Ulice stawały się coraz bardziej bezludne. To komplikowało zadanie. Na szczęście latarnie były znacznie rzadsze, zaś niemal czarny płaszcz ułatwiał krycie się w mroku. Gumowe podeszwy zapobiegały powstawaniu jakichkolwiek odgłosów. Sierakowski od dawna przestał być nowicjuszem w służbie" (s. 28-29). Po części funkcję tę pełni również garnitur w Barwach strachu Krystyna Ziemskiego: tłumaczący się z założenia go protagonista tej powieści deklaruje: „To [...] służbowe spotkanie. [...] Tyle że w knajpie. Umówiłem się z dziewczyną, która może mi dostarczyć interesujących informacji w sprawie, którą przejąłem" (idem, Barwy strachu, Warszawa 1981, s. 37). Szerzej wątek ubrania kamuflażu rozwija w powieści „neomilicyjnej” Ryszard Ćwirlej, expressis verbis wskazując na taką rolę stroju funkcjonariuszy: „Brodziak wziął go na bok i wythumaczył, że w ich wydziale chodzi się do roboty w cywilnych ciuchach, dzięki którym milicjanci upodabniają się do zwykłych obywateli. On na przykład ubiera się jak cinkciarz, Marcinkowski jak nauczyciel matematyki, Olkiewicz jak szuszwol [reg.: obdartus — A.M.] w niedzielę, więc teraz Mariusz powinien sam sobie wybrać swój image" (idem, Masz to jak w banku, Warszawa 2018, s. 136). Osobną kwestią pozostaje reprezentowana przez bohaterów świadomość przemian obyczajowych, wyrażająca się również w doborze strojów. Jest to kwestia rzadko pojawiająca się w powieści milicyjnej, zatem na tym większą uwagę zasługuje ten wątek w powieści Gertrudy R. Sławek, W matni, Warszawa 1986, s. 113; czytamy: „Będąc długoletnim funkcjonariuszem Służby Bezpieczeństwa pamiętał czasy, kiedy jedynym dopuszczalnym w tym zawodzie ubiorem był ciemny garnitur albo, w najgorszym przypadku, marynarka z nieodłącznym krawatem. Zdawał sobie jednak sprawę, że upieranie się przy dotychczasowych kanonach pachnie anachronizmem i dlatego też pozwalał swoim podwładnym na pewną swobodę w ubiorze, wyłączając oczywiście wszelkie oficjalne imprezy". 
może nosić poza godzinami pracy ${ }^{17}$. Zostaje przywołany zazwyczaj jako strój funkcjonujący w roli punktu odniesienia dla ubrania bohatera; jedynie niekiedy — jak we Włamywaczach (1971) Zbigniewa Safjana — pojawia się sygnał „tęsknoty za mundurem", sprawiającym, że bohater czuje się traktowany przez innych w sposób poważny: „I tak jestem dostatecznie śmieszny, myślał, w tym cywilnym

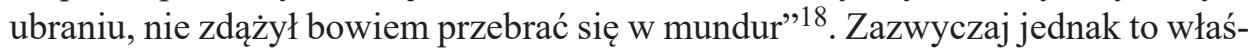
nie „strój cywilny” (resp. garnitur) dominuje, ponieważ jest bardziej uniwersalny (a w domyśle - również wygodny). Reprezentatywną dla takiego obrazowania zdaje się uwaga narratora jednej z powieści Kazimierza Korkozowicza — Białym ptaszczu w brazowa kratę (1975); w utworze protagonista ,używał munduru tylko w koniecznych przypadkach. Wolał ubrania cywilne"19.

Owszem, garnitur może być zgodny z najnowszymi trendami (to domena kreacji milicjanta światowca) bądź ukazany jako niezbyt dopasowany (casus postaci, z którą mógłby identyfikować się czytelnik), lecz musi być schludny; znacząca pod tym względem pozostaje uwaga w powieści Anny Kłodzińskiej Grzęzawisko na temat powodów, dla których jeden ze śledczych woli działać w ukryciu: „Sierżant nie chciał mówić wprost, ale Kulczyc zrozumiał. Kiedy pracuje się w taki sposób, niewygodnie jest na przykład pokazywać się szefom w stanie lekkiej nieważkości i pomiętym garniturze [wyr. - A.M.]"20. Niemniej jest on w świecie przedstawionym ubiorem obowiązkowym. Toteż wszelkie odstępstwa od dress code były traktowane przez innych bohaterów jako znamiona nieprofesjonalizmu (niekiedy mylne); przykładem służy reakcja Szczęsnego — protagonisty powieści Grzęzawisko (1981) Anny Kłodzińskiej na widok ubranego po cywilnemu funkcjonariusza:

Kapitan Tomasz Kulczyc [...] był w sportowej bluzie i jasnych spodniach, przypominał któregoś z aktorów czy piosenkarzy, zwłaszcza że głos miał melodyjny i wyraźnie wymawiał słowa. To wszystko usposobiło majora Szczęsnego [do rozmówcy - A. M.] mało życzliwie ${ }^{21}$.

17 Zob. rozporządzenie Ministra Bezpieczeństwa Publicznego z dnia 29 września 1948 roku o umundurowaniu i oznakach służbowych funkcjonariuszów Milicji Obywatelskiej, Dz.U. z 1948 r. $\mathrm{Nr} 47$, poz. 357, z późń. zm., s. 963-965; zarządzenie nr 42/55 MSW w sprawie wprowadzenia przepisów ubiorczych dla funkcjonariuszy MO i kursantów szkół MO oraz w sprawie określenia terminu i kolejności wprowadzania nowego koloru umundurowania MO obowiązujące od 1 maja 1955 roku do 29 października 1969 roku [L.dz. AB-741/55]; zarządzenie nr 55/74 MSW w sprawie przepisów ubiorczych funkcjonariuszy Milicji Obywatelskiej obowiązujące od dnia podpisania, to jest 30 lipca 1974 roku do dnia 9 sierpnia 1990 roku [L.dz. PMŻ-453/74]. Należy przy tym zaznaczyć, że w ustawie z dnia 31 lipca 1985 roku istnieje przepis o możliwości wykonywania obowiązków służbowych bez obowiązku noszenia umundurowania (zob. ustawa z dnia 31 lipca 1985 roku o służbie funkcjonariuszy Służby Bezpieczeństwa i Milicji Obywatelskiej Polskiej Rzeczypospolitej Ludowej, Dz.U. z 1985 r. Nr 38, poz. 181, art. 37, § 2.

18 Z. Safjan, Włamywacze, Warszawa 1971.

19 K. Korkozowicz, Biaty plaszcz w brązowa krate, Warszawa 1975, s. 5.

20 A. Kłodzińska, Grzęzawisko, Warszawa 1981, s. 238.

${ }^{21}$ Ibidem, s. 96. 
Do pewnego stopnia można owo zauroczenie garniturem wyjaśnić faktem, iż - zwłaszcza w latach siedemdziesiątych XX wieku - kreatorem masowego gustu była telewizja. Wówczas to pojawiły się w niej pierwsze produkcje zachodnie o charakterze obyczajowo-sensacyjnym, między innymi seriale: Pogoda dla bogaczy (Rich Man, Poor Man, reż. David Greene i in., USA 1976), Kojak (Kojak, reż. Charles S. Dubin i in., USA 1973-1976) i Columbo (Columbo, reż. Richard Irving i in., USA 1968-1978), stanowiące dla Polaków punkty odniesień do własnych wyborów w zakresie mody i namiastki stylu życia ${ }^{22}$.

Nieco inny wymiar ma natomiast fakt noszenia garnituru oraz umundurowania przez milicjantów w utworach powstałych w latach osiemdziesiątych. Wówczas to decyzja o doborze ubrania stała się gestem nacechowanym politycznie, ponieważ - co podkreśla Marta Kargól — elegancki strój pozostawał wyrazem opowiedzenia się noszącego go za politycznym status quo:

W realiach polskiego komunizmu wykształcił się swoisty styl opozycji. Jego cechą była rezygnacja z krawatu, a czasem nawet z marynarki. Garnitur był postrzegany jako strój przedstawicieli władzy. Flanelowa koszula w kratę, sweter i chlebak były codziennym ubiorem robotników, [...] ale stały się także znakiem walczących z systemem komunistycznym ${ }^{23}$.

Odczytywany w zaproponowanej tu przez badaczkę perspektywie antropologicznej garnitur (a tym bardziej mundur służbowy) staje się — przywołajmy sformułowanie Józefa Szymańskiego — strojem będącym formą rytuału prawnego $^{24}$. Wybór stroju kojarzonego z klasyczną elegancją — a tak właśnie ubierali się protagoniści powieści milicyjnej - staje się zatem wyborem ideologicznym, wzmocnionym (zwłaszcza w okresie stanu wojennego, ale i później) wypowiedziami prasowymi, w których eksponowana zostaje rola organów porządkowych w utrzymaniu ładu, zgodnie z oczekiwaniem społeczeństwa ${ }^{25}$.

Co ciekawe, zanikają wówczas opisy szczegółowe ubrania (przytoczony opis stroju Kulczyca pozostaje wyjątkiem $)^{26}$. W ich miejsce pojawiają się ,,mikrosugestie": krawat (W pogardzie prawa, 1983, Kłodzińskiej), pasek milicyjnej czapki (Grzęzawisko, 1981, Kłodzińskiej), garnitur (Barwy strachu, 1981, Krystyna Ziemskiego; W matni, 1986 Gertrudy R. Sławek) lub — ogólnikowo — mundur (U progu nicości, 1983, Jerzego Parfiniewicza). Można traktować je jako zabiegi

22 Zob. D. Wiliams, G. Sołtysiak, Modny PRL, Warszawa 2016, s. 212-213.

23 M. Kargól, Szarość, brud, brzydota. Niedbalstwo jako (nie)zamierzona forma komunikacji, „Fragile” 2014, nr 1, s. 96.

24 Zob. J. Szymański, Nauki pomocnicze historii, Warszawa 1983, s. 564-565.

25 Przykładowo: „Kto, jak nie otoczone zaufaniem i szacunkiem społeczeństwa organa porządku publicznego, Milicji Obywatelskiej czy Służby Bezpieczeństwa, stać powinny na straży tego ładu, który jest najwyższym i nadrzędnym dobrem Polaków?" ([?], Strzały na Placu św. Piotra, „Rzeczywistość” 1981, nr 1, s. 1).

26 Oczywiście również w chronologicznie wcześniejszych powieściach można spotkać uogólnione opisy stroju funkcjonariuszy; przykładem służy utwór Jerzego Edigeya Najgorszy jest poniedziałek, Warszawa 1975, s. 195: „Na widok dwóch mężczyzn ubranych po cywilnemu i milicjantów w mundurach odruchowo się cofnął [wyr. - A.M.]". 
o charakterze metonimii, waloryzujące bohaterów utworu; w tej samej roli pojawia się kraciasta koszula noszona przez zwolennika społecznej anarchii, wywodzącego się z przestępczego półświatka w utworze Kłodzińskiej W pogardzie prawa ${ }^{27}$.

\section{Kreacja protagonisty, w której podkreślony byłby wzorcotwórczy charakter wyglądu zewnętrznego i dbałość o jego reprezentacyjność}

Bohaterowie powieści milicyjnej, w których kreacji podkreślony zostaje styl i elegancja wyglądu, ubierają się zgodnie z modą stworzoną na potrzeby klasycznego gustu, identyfikowanego z „byciem dżentelmenem”, łączącego „,dobry wygląd" $z$ erudycją ${ }^{28}$. Wygląd zewnętrzny staje się wówczas reprezentacją cech osobowości pożądanych u funkcjonariusza MO: powściągliwości, opanowania, kultury osobistej ${ }^{29}$. Pozwala też na aspirowanie bohatera do elity społecznej, definiowanej w sposób zgodny z zasadami merytokracji, czyli (w myśl koncepcji Michaela Younga) opierając się na wykształceniu na podstawie zasady kompe-

27 „Mężczyzna w kraciastej koszuli wdarł się do wozu, chwycił kaprala za krawat i począł zaciskać” (A. Kłodzińska, W pogardzie prawa, Warszawa 1983, s. 76). W kontekście wcześniejszych uwag Kargól na temat mody stanu wojennego jest to scena jednoznacznie ukazująca starcie dwóch sił: porządku, reprezentowanego przez milicjanta i anarchii, reprezentowanej przez napastnika, nieprzypadkowo noszącego strój odpowiadający dress code’owi zwolenników NSZZ „Solidarność”.

28 Zob. B. Roetzel, Gentleman: moda ponadczasowa, przeł. J. Pokora, M. Rulski-Bożek, S. Ratajczyk, Ożarów Mazowiecki 2009. Co ciekawe, ten sposób kreowania milicjanta na człowieka obytego w świecie wykroczył poza nurt powieści milicyjnej. Jego pogłos można odnaleźć w reprezentującym „realizm satyryczny” — utworze Józefa Łozińskiego, Sceny myśliwskie z Dolnego Śląska, Warszawa 1985, s. 79; czytamy: „Był to mężczyzna bardzo przystojny, trzydziestopięcioletni, z drażniącym tikiem lewego oka [...]. Nienaganna kultura osobista czyniła z niego milicjanta-humanistę i pułkownik [...] z zatroskaniem obserwował naukowe metody pracy z politycznymi przestępcami z odrazą odrzucające bicie i wyszukane tortury. Pułkownik [...] miał do swego uroczego podwładnego zdumiewającą słabość, a polegała ona na tym, że podziwiał jego biegłą angielszczyznę i szeroką znajomość problemów świata kapitalistycznego".

29 Nieprzypadkowo twórcy podręcznika savoir-vivre’u dla milicji podkreślali: „Od milicjanta społeczeństwo wymaga i spodziewa się więcej taktu, kultury, poprawności w zachowaniu się niż od każdego przeciętnego obywatela (I. Gumowska, J. Kapica, op. cit., s. 3). Oczywiście cechy te miały charakter sekundarny wobec innych przymiotów funkcjonariusza MO, definiowanych już na wczesnym etapie tworzenia aparatu milicyjnego. Stanisław Radkiewicz deklarował wówczas: „Nam potrzebny jest nowy typ milicjanta, typ świadomego obywatela, sługi państwa demokratycznego. Wysoka duchowa, etyczna i moralna postawa, bezgraniczne oddanie sprawie Polski, ideowy patriotyzm - to powinno cechować nowego milicjanta. W tym duchu musimy wychowywać naszą milicję. Drogą systematycznej pracy polityczno-wychowawczej, rozbudową całego systemu dokształcania i nauki, bezlitosnym trzebieniem wszelkich naleciałości i wypaczeń" (idem, Milicjant szermierzem demokracji, „Na Straży Demokracji” 1945, nr 1, cyt. za: P. Majer, Milicja Obywatelska 1944-1957, s. 142). 
tencji ${ }^{30}$. Hierarchia „dobrego urodzenia” (w rozumieniu ideologicznym jako pochodzenia robotniczo-chłopskiego) oczywiście nadal odgrywa dość istotną rolę ${ }^{31}$. Jednakże przynależność do sfery inteligencji nie jest w powieści milicyjnej nacechowana w sposób jednoznacznie negatywny ${ }^{32}$.

Wzorowany na klasycznej modzie męskiej wygląd służy jednakże nie tylko promowaniu określonego sposobu ubierania się; to również — w myśl rozpoznania Efrat Tseëlon — sygnał potwierdzenia własnych kompetencji bohatera; czytamy:

Bycie niestylowym z całą pewnością może powodować straty wizerunkowe. Ukryty przekaz kulturowy takiego normatywnego klimatu mówi, że „nieumiejętność bycia ikoną mody" postrzegana jest jako oznaka innych niedoborów ${ }^{33}$.

30 Zob. M. Young, Introduction to the Transaction Edition, [w:] idem, The Rise of the Meritocracy [prwdr. 1958], New Brunswick-London 2008, s. XIV. O rodzimych zideologizowanych odczytaniach obserwowanych przez Younga zmian zob. M. Brzóstowicz-Klajn, Od inteligenta do fachowca. O projektowanej przemianie inteligencji w świecie wykreowanym w socrealistycznej literaturze, [w:] Presja i ekspresja. Zjazd szczeciński i socrealizm, red. D. Dąbrowska, P. Michałowski, Szczecin 2002, s. 167-179. Co istotne, takie ahistoryczne spojrzenie pozostaje w pełni usprawiedliwione, Brzóstowicz-Klajn ukazuje bowiem uniwersalny w obrębie kultury socjalistycznej mechanizm zmian społecznych; jego oddźwięki można zresztą dostrzec również w „powieści neoprodukcyjnej” (,dyrektorskiej”) powstałej w latach siedemdziesiątych XX wieku.

31 Jest to widoczne zwłaszcza w prozie autorów zbliżonych ideowo do koncepcji elitaryzmu politycznego środowiska „Rzeczywistości”, zrzeszającego zwolenników dogmatycznego socjalizmu (na temat założeń ideowych i wizji ładu społecznego tego odłamu PZPR zob. K. Podemski, Obrazy i wizje społeczeństwa polskiego w prasie krajowej w 1981 roku, Poznań 2008, s. 111-116). Jako przykład mogą służyć opublikowane we wczesnych latach osiemdziesiątych XX wieku powieści Anny Kłodzińskiej: Grzęzawisko (1981), W pogardzie prawa (1983), Zdrajca (1984), Malwina przegrała milion (1984). Nieprzypadkowo przecież w recenzji jednej z powieści tej pisarki czytamy: „Anna była kobietą wierzącą, wierzyła w socjalizm, potem wierzyła w Moczara, i w Jaruzelskiego, wierzyła że Stan Wojenny jest potrzebny i pomocny" (J. Kiereński, Grzęzawisko - Czyli Dyrektory to Potwory..., [rec. A. Kłodzińska, Grzęzawisko], „Klub Mord”, http://www.archiwum.klubmord.com/Recenzje/klodzinska-anna-grzezawisko-jk.html (dostęp: 30.01.2018). Z kolei w powieści Barbary Gordon (właśc. Larysy Mitzner) Dolina nocy (1980) protagonista służył w MO od początku jej istnienia.

32 Znaczący pod tym względem pozostaje casus Jerzego Moczarskiego — bohatera powieści Ryszarda Szczerby, Szakale, Warszawa, 1959, s. 7, który otrzymawszy formację charakterystyczną dla inteligencji przedwojennej, wykorzystuje ją w codziennej pracy: „Wychowany w rodzinie inteligenckiej, otrzymał to, co Niemcy nazywają »Kinderstube«. Wykształcony i oczytany należał do czołówki pracowników służby kryminalno-śledczej”. Taka zarysowana na kartach powieści reorientacja polityki kadrowej pozostawała w jawnej sprzeczności z praktyką zwłaszcza początkowego okresu istnienia MO (lata 1945-1949), kiedy to o naborze w szeregi MO decydowało pochodzenie społeczne (zob. P. Majer, Milicja Obywatelska 1945-1957, s. 142-157). W latach późniejszych wprawdzie złagodzono restrykcyjne wymagania, jednak z nich nie zrezygnowano.

33 E. Tseëlon, Modele przejścia: o przeobrażeniach kulturowej roli modelki, [w:] Moda: model(ka) i czytelnicy. O ikonicznych reprezentacjach w kulturze, red. M. Gołąb, N. Schiller, Łódź 2015, s. 24. Nie inaczej ukazuje relację między strojem a stereotypowym postrzeganiem jednostki Barbara Sobczak wskazująca na rolę ubioru w pozawerbalnym konstruowaniu wiarygodności przez jednostkę, która za jego pomocą może wpływać na stosunek do siebie innych ludzi (zob. eadem, Retoryka a niejęzykowe środki komunikacji, „Poznańskie Studia Polonistyczne. Seria Językoznawcza” 15, 2009, s. 74). O tym, do jakiego stopnia naszkicowane tu traktowanie garnituru pozostaje zakorzenione w wyobraźni społecznej, świadczą uwagi na jego temat w podręczniku akademickim z zakresu 
Uwaga interpretacyjna Tseëlon pozostaje istotna zwłaszcza w kontekście sygnalizowanej uprzednio przez Younga tendencji do profesjonalizacji, utożsamianej z merytokracją jako nowym kryterium przynależności do elity społecznej ${ }^{34}$.

Przykładem utworu, w którym obserwujemy naszkicowany tu model wzorcotwórczej kreacji protagonisty, jest powieść Piotra Guzy Wenus z brązu (1956):

Kapitan Szymon Cypryn z wydziału śledczego Wojewódzkiej Komendy Milicji w Poznaniu [...] ubierał się zwykle bardzo starannie, więcej nawet - zgodnie z bieżącą modą, aczkolwiek robił to $\mathrm{z}$ dyskrecją i umiarem. Nie nosił nigdy innych koszul jak białe z półsztywnym kołnierzykiem; jego krawaty, wiązane w zręczny węzeł, były gładkie, jednego, zdecydowanego koloru, [...] spodnie były zawsze nienagannie wyprasowane, mankiety czyste, buty wyczyszczone ${ }^{35}$.

Zróżnicowanie jakościowe informacji w cytowanym tu passusie jest nieprzypadkowe: czytelnik najpierw otrzymuje dane na temat stanowiska i miejsca pracy protagonisty, dopiero zaś w dalszej kolejności na temat jego wyglądu i sposobu ubierania się. Kolejność taka nie jest przypadkowa: należy pamiętać, że — z perspektywy perswazji literackiej — znaczące staje się miejsce pracy bohatera: w drabinie zależności służbowych komenda wojewódzka to szczebel dość wysoki ${ }^{36}$. Tym samym praca w niej oraz korespondujący ze statusem służbowym wygląd dodatkowo podkreślają zależność między własnymi uzdolnieniami i kompetencjami protagonisty a zajmowanym przezeń stanowiskiem ${ }^{37}$. Jednakże nie tylko oficerowie wyżsi stopniem potrafią dobrać odpowiedni strój; w Maskotce (1978) Jana Koprowskiego elegantem jest sierżant: „Stwierdził, że w nowo nabytym ostatnio letnim garniturze, eleganckiej koszuli oraz modnym, szerokim krawacie, zawiązanym w gruby węzeł, prezentował się rzeczywiście jak obywatel zasobny w gotówkę"38.

wizerunku biznesowego: „Garnitur to najbardziej standardowy i powszechnie obowiązujący strój biznesowy dla panów. Dobry jakościowo, odpowiednio dobrany do sylwetki garnitur zapewnia profesjonalny wygląd” (K. Kowalska, A. Łakoma, B. Szymoniuk, Wizerunek biznesowy, Lublin 2011, s. 58).

34 Sygnałem wzmiankowanej tu zależności pozostaje zapis na temat warunków koniecznych do awansu służbowego w ramach struktur organizacyjnych MO: „Na wyższe stanowisko służbowe mianuje się funkcjonariusza w ramach wolnych stanowisk w zależności od opinii służbowej i posiadanych kwalifikacji” (dekret z dnia 20 lipca 1954 roku o Milicji Obywatelskiej, Dz.U. z 1954 r. $\mathrm{Nr} 34$, poz. 143, art. 12).

35 P. Guzy, Wenus z brazu, Warszawa 1956, s. 50-51.

36 Zob. P. Majer, Model Milicji Obywatelskiej realizowany w latach 1944-1990, [w:] Policja w Polsce. Stan obecny i perspektywy, t. 1, red. A. Szymaniak, W. Ciepiela, Poznań 2007, s. 27-50.

37 Jedynie niekiedy, jak w Rendez-vous w hotelu „,Royal” Andrzeja Barcza, garnitur staje się metonimią munduru, pozwalając rozpoznać milicjanta pełniącego służbę: „Wstał już z leżaka, gdy kątem oka dostrzegł dwóch mężczyzn w garniturach, z trudem przeciskających się wśród rozłożonych ciasno obok siebie nagich ciał. Na ich widok usiadł z powrotem, rozglądając się za skarpetkami. [...] Paweł wiedział już, co się za chwilę stanie. Dostrzegli go i szli w jego stronę. Włożył koszulę.

— Panie poruczniku — zaszeptał mu do ucha jeden z nich, nachylając się nad leżakiem — Stary kazał was znaleźć i jak najprędzej przywieźć do komendy” (idem, Rendez-vous w hotelu ,Royal ", Warszawa 1978, s. 8).

38 J. Koprowski, Maskotka, Warszawa 1978, s. 38. 
Jeśli zaś nie jest opisany szczegółowo wygląd zewnętrzny milicjanta, analogiczną funkcję pełni charakterystyka osobowości protagonisty, w której podkreślone zostają dobre maniery i opanowanie, właściwe wzorcowemu funkcjonariuszowi:

[Jan Smolak] Spokojny i flegmatyczny, niezwykle skrupulatny, o charakterystycznej, nieco przedwcześnie pokrytej zmarszczkami twarzy i lekko już siwiejących włosach, w stosunku do podejrzanych zachowywał się niemal kurtuazyjnie, wielu wyraźnie współczując ${ }^{39}$.

Stylistyczną wariacją w realizacji naszkicowanej tu strategii jest zastąpienie szczegółowego opisu wyglądu bohatera lapidarnym sformułowaniem, które pozostaje jasne jedynie dla czytelnika znawcy; oto w utworze Andrzeja Barcza Rendez-vous w hotelu ,Royal” czytamy: „Oprócz majora Biesagi w gabinecie siedział nie znany mu mężczyzna w jasnym tropikowym garniturze"40. Dookreślenie rodzaju materiału, z którego uszyto odzienie bohatera, pozwala rozpoznać kod mody, którym mężczyzna kierował się w wyborze elanowełny (czyli owego tropiku); była to przecież jedna z najmodniejszych tkanin w PRL, stosowana $\mathrm{w}$ latach siedemdziesiątych (to jest w czasie stanowionym, a zarazem publikacji utworu Barcza) do produkcji koszul non-iron, traktowanych jako ikona ówczesnego stylu, obecną w modzie polskiej od lat sześćdziesiątych XX wieku (alternatywą była kremplina, zwana bistorem, o podobnych właściwościach $)^{41}$.

Tym samym, zgodnie z sugestią Rolanda Barthes'a, ubiór staje się symbolem dostępnym jedynie dla wybranych, potrafiących odczytać jego przesłanie ${ }^{42}$. Odzież tworzy zarazem obraz wspólnoty, do której należy zarówno bohater literacki, jak i obserwujący jego przygody czytelnik; tym, co ją konstytuuje, jest znajomość kodu ubioru, dostępna jedynie wybranym (resp. elicie), do których kręgu pretenduje również odbiorca.

39 R. Szczerba, Alibi, Warszawa 1973, s. 4-5.

40 A. Barcz, op. cit., s. 25.

41 Zob. Kronika PRL, t. 16. Moda, Warszawa 2015, s. 76; D. Wiliams, M. Sołtysiak, op. cit., s. 231-233. O tym, do jakiego stopnia były to tkaniny modne, zakorzenione w świadomości społecznej, świadczy, że ich potoczne nazwy (non-iron, bistor) zostały odnotowane nie tylko w języku ogólnym, lecz także gwarach (zob. D. Bieńkowska, Zapożyczenia z języka literackiego w gwarach okolic Bełchatowa, „Acta Universitatis Lodzendzis. Folia Linguistica” 1987, nr 16, s. 221-236).

42 Zob. R. Barthes, System mody, przeł. M. Falski, Kraków 2005, s. 27. Jest to możliwe jedynie dzięki umiejętności dostrzeżenia i odkodowania struktury znaków tego, co badacz określa mianem „ubioru pisanego", to jest językowej reprezentacji danego stroju. Zob. ibidem, s. 21. Relacje między oboma reprezentacjami jednego desygnatu Barthes ukazuje następująco: „Widzę, że chodzi tu o dwa różne ubiory. Pierwszy z nich został mi przedstawiony jako fotografia lub rysunek, jest to ubiór-obraz. Drugi to ten sam ubiór, lecz opisany, przekształcony w język. [...] W zasadzie oba te ubiory odsyłają do tej samej rzeczywistości [...], a jednak nie mają tej samej struktury" (ibidem, s. 22). 


\section{Stworzenie image'u „równiachy"/,swojaka", z którym mógłby identyfikować się modelowy czytelnik}

Jest to strategia artystyczna nie tyle opozycyjna wobec naszkicowanej, ile raczej wobec niej komplementarna. Model postaci, w którym czytelnik odnajduje cechy własnej osobowości, pozwala nie tylko „oswoić” bohatera tak, iż przestaje być on „egzotyczny” (to właściwość postaci literackich milicjantów, odnośnie do których obserwujemy — z perspektywy psychologii odbioru — istnienie mechanizmu projekcji). W wypadku bohatera, z którym czytelnik się identyfikuje, mówi o pojawieniu się funkcji kompensacyjnej: czytający doznaje tym większego emocjonalnego „pocieszenia”, obserwując, w jaki sposób protagonista radzi sobie z przeciwnościami losu, im bardziej potrafi utożsamić się z literacką postacią ${ }^{43}$. Zabiegowi temu podporządkowana jest taka kreacja bohatera, w której uwypuklone zostają różnorodne usterki w wyglądzie i maniery zachowań, traktowane najczęściej dość pobłażliwie. Postacią reprezentatywną dla kreacji image’u „swojego chłopa” jest bohater opowieści Zbigniewa Safjana Włamywacze: „Stasia po prostu nie dostrzegają ze względu na niepozorny wygląd, niski wzrost, brak dostatecznie tubalnego głosu i milczenie na zebraniach" ${ }^{\text {44 }}$.

Niepozorność staje się kluczem do sukcesu również w Grzęzawisku Kłodzińskiej; w utworze tym wywiadowca milicyjny ukazany jest w następujący sposób:

Spoza ogromnej postaci Maleńkiej wychylił się niespodziewanie mężczyzna w szarej kurtce i w czapce z daszkiem, szczupły, z niewielkim czarnym wąsikiem. Bystrym okiem popatrzał na kamerę, której Maleńka nie zdążyła wsunąć do torby ${ }^{45}$.

Z kolei tytułowy bohater jednej z powieści Barbary Gordon Błędu porucznika Kwaśniaka (1983), określany jest wprost jako „mister przeciętności”:

43 Być może należałoby też potraktować kategorię nijakości — właściwą kreacji bohatera „swojaka” — jak element topiczny, przejęty z literatury zachodniej (przede wszystkim prozy Raymonda Chandlera). Z zaproponowanej tu perspektywy mielibyśmy do czynienia z przejawem recepcji twórczości zachodniej i jej wpływem na sposób obrazowania protagonisty powieści milicyjnej. Supozycji tej przeczyłoby jednak przywoływane uprzednio, negatywne nastawienie krytyki literackiej do tłumaczeń zachodniej prozy sensacyjno-kryminalnej (zwłaszcza amerykańskiego nurtu „czarnego” kryminału). Przykładowo: „Amerykanie się szczycą — a niech się szczycą! — tym, że kraj ich jest kolebką, ojczyzną, oazą i Bóg wie czym jeszcze autorów powieści kryminalnych. Powiadają: nasze powieści kryminalne są przykładem samokrytycyzmu narodowego, są ujściem znanych amerykańskich skłonności do gwałtu, sadyzmu i masochizmu. W oczach wielu socjologów są one nieszkodliwą klapą bezpieczeństwa dla wyżej wymienionych miłych cech, są lekarstwem powodującym odprężenie, nakazują szanować prawo, kształtują pion moralny młodego pokolenia, pokazują triumf zła nad dobrem. Zupełnie jak uniwersalny środek na porost włosów, który jednocześnie leczy wątrobę. [...] Lepiej trzymać się z daleka od znakomitej większości amerykańskiej szmiry kryminalnej, która w myśl zasady »umoralniania« propaguje sadyzm, gwałt, zboczenia i zezwierzęcenie" (M. Zakrzewski, op. cit., s. 7).

44 Z. Safjan, op. cit., s. 15.

45 A. Kłodzińska, Grzęzawisko, s. 181. 
Ani niski, ani wysoki, ani gruby, ani chudy, twarz w tłumie nie do odróżnienia i nie do rozpoznania [...] Jasiu — mówili na niego wszyscy w wydziale. Nie dodawali wprawdzie przymiotnika głupi, bo właściwie go lubili, ale zaraz potem następowało nieco lekceważące machnięcie ręką ${ }^{46}$.

Przyczyną niedopasowania do roli milicjanta światowca może też być — niczym w powieści Macieja Z. Bordowicza Toccata (1972) — młody wygląd bohatera:

Porucznik Adam Płoński, zmęczony nieco ślubem, przyjęciem i czernią garnituru, siedzi wraz z młodziutką małżonką [...] na tapczanie [...]. Adam trochę niezgrabnie wygląda w czerni garnituru, a już szczególnie wstążeczka z gałązką asparagusa w klapie marynarki — przy jego chłopięcej, trochę nerwowej twarzy — sprawia, że wszystko to razem wygląda dość głupio ${ }^{47}$.

Nie inaczej przedstawiony jest jednak również starszy wiekiem bohater powieści Andrzeja Zbycha (właśc. Andrzeja Szypulskiego i Zbigniewa Safjana) Bardzo dużo pajacyków (1968):

Nikt z mijających go obojętnie przechodniów nie rozpoznałby inspektora wydziału śledczego milicji w tym podtatusiałym, ubranym w workowaty garnitur mężczyźnie. To zabawne, ale każde ubranie wisi na nim jak worek. Przywykł ubierać się zwyczajnie w konfekcję, kiedyś przed laty przydzielaną na talony, później z trudem kupowaną w sklepach oznaczonych numerami, ostatnio zaś w salonach odzieżowych o ekskluzywnych nazwach „Gentleman” czy „Mister”, ale każde, najlepiej nawet wyglądające na manekinie ubranie stawało się, gdy włożył je Olszak, popielatawym (lubił ten kolor) workiem ${ }^{48}$.

Tym, co łączy bohaterów powieści Bordowicza i Zbycha, jest możliwość identyfikacji z nimi odbiorcy, potrafiącego dostrzec w Płońskim i Olszaku własne alter ego. Są oni tak przeciętni (tak też postrzegają ich inni powieściowi bohaterowie), że unieważniony zostaje charakterystyczny dla milicjanta światowca dystans, mający źródło w wyglądzie. Zarazem typowość wyglądu zostaje skontrastowana z walorami umysłu i dociekliwością bohaterów, potrafiących odnaleźć sprawców ukazanych w obu powieściach zbrodni.

$$
* * *
$$

Kreacja postaci milicjanta - traktowanego jako figura reprezentatywna dla określonego typu bohaterów literackich, charakterystycznych dla powieści milicyjnej — była sfunkcjonalizowana tak, aby ukazać milicjantów jako bohaterów

46 B. Gordon, Błąd porucznika Kwaśniaka, Warszawa 1983, s. 12.

47 M.Z. Bordowicz, Toccata, Warszawa 1972, s. 11.

48 A. Zbych, Bardzo dużo pajacyków, Warszawa 1968, s. 100. Uwaga na temat szarości jako ulubionego koloru protagonisty nie jest obojętna aksjologicznie: może być sygnałem konserwatyzmu, zwłaszcza w konfrontacji z realiami pozatekstowymi; przypomnijmy, iż męska moda lat sześćdziesiątych XX wieku cechowała się kontrastowością kolorystyki a funkcją ubrania było odmłodzenie noszącego go (zob. Kronika PRL, t. 16. Moda, s. 75). 
na służbie i poza nią. Dlatego też swój niepozorny wygląd wykorzystywali oni jako „broń” w walce z przestępcami ${ }^{49}$. Z kolei dżentelmen światowiec, ewokując mechanizm projekcji, pozwalał tworzyć wzorzec „milicjanta idealnego”. Obie strategie zaś - w myśl rozpoznania Wojciecha Piotra Kwiatka — miały budzić zaufanie do służb śledczo-porządkowych, nadużyte w okresie stalinowskim:

Kreując [...] bohatera, autorzy nasi realizują jeden [...] cel: starają się wywołać u odbiorcy przekonanie, że takim ludziom można bezwzględnie zaufać. Bo jakże nie mieć zaufania do kogoś, kto cieszy się powszechną sympatią, kto dzięki swym manierom i aparycji jest w stanie załatwić każdą sprawę? A jeżeli nawet bohater nie jest przystojny? Tym lepiej. Za to jest pracowity, rzetelny, odpowiedzialny jak dobry, solidny urzędnik. Na pewno nie spocznie, póki nie zapnie sprawy na ostatni guzik ${ }^{50}$.

W ten sposób „nadludzie w niebieskich mundurach” (określenie Stanisława Barańczaka ${ }^{51}$ ) (od)zyskiwali swój ludzki wymiar, stając się — zgodnie z założeniami ideologicznymi, choć z innych powodów niż planowaliby to państwowi decydenci — bliżsi czytelnikom.

O tym, do jakiego stopnia wykreowany przez twórców powieści milicyjnej portret funkcjonariusza pozostał współcześnie nośny artystycznie, świadczą jego rekonfiguracje w nurcie „powieści neo-milicyjnej”, będącej twórczością o charakterze demistyfikującym. Jednakże dziś nie tylko ów nurt rozrachunkowy, ale i powieść milicyjna przeżywa renesans zainteresowania, o czym świadczy aktywność internetowa jej miłośników. Podwodem, dla którego owe - nierzadko przecież przesycone propagandą — opowieści znajdują swych czytelników, mogą być jej walory dokumentarne ${ }^{52}$. Wydaje się jednak, że przede wszystkim o modzie na nią decydują obrazy bohaterów, postrzeganych obecnie nie tyle jako przedstawiciele władzy, ile jednostki, radzące sobie z codziennymi niedogodnościami życia w PRL.

49 Niekiedy zresztą niepozorny wygląd jako kamuflaż wykorzystywany jest nie tylko przez funkcjonariuszy MO — w powieści Zbycha Bardzo dużo pajacyków pojawia się były żołnierz Polski Podziemnej, należący podczas okupacji hitlerowskiej do formacji zajmującej się egzekucjami i kontrwywiadem. Jest on przedstawiony jako nijaki starszy mężczyzna: „,[Olszak] usiłował sobie wyobrazić tego szarego mężczyznę w wyświeconym garniturze, w zawiązanym na nieforemny węzeł krawacie, o niezbyt starannie ogolonych policzkach, jako żołnierza podziemnej armii, tej części armii, której przeznaczeniem były zadania najcięższe: wykonywanie wyroków, tropienie zdrajców" (ibidem, s. 103).

50 P.W. Kwiatek, Zagadki bez niewiadomych, czyli kto i dlaczego zamordowat polska powieść kryminalna, Warszawa 2007, s. 57.

51 Zob. S. Barańczak, W kręgu powieści: nadludzie w niebieskich mundurach, [w:] idem, Czytelnik ubezwłasnowolniony. Perswazja w masowej kulturze literackiej PRL, Paryż 1983, s. 96-132.

52 Zob. D. Skotarczyk, Pierwsze i drugie życie powieści milicyjnej, [w:] Popkomunizm. Doświadczenie komunizmu a kultura popularna, red. M. Bogusławska, Z. Grębecka, Kraków, s. 101-110. 


\section{Bibliografia}

\section{Teksty}

Barcz A., Rendez-vous w hotelu „,Royal”, Iskry, Warszawa 1978.

Bordowicz M.Z., Toccata, Iskry, Warszawa 1972.

Ćwirlej R., Masz to jak w banku, Warszawskie Wydawnictwo Literackie „Muza”, Warszawa 2018.

Edigey J. [właśc. J.W. Korycki], Testament samobójcy, Czytelnik, Warszawa 1972.

Gordon B. [właśc. L. Mitzner], Bład porucznika Kwaśniaka, Iskry, Warszawa 1983.

Gordon B. [właśc. L. Mitzner], Dolina nocy, Iskry, Warszawa 1980.

Guzy P., Wenus z brazu, Wydawnictwo Ministerstwa Obrony Narodowej, Warszawa 1956.

Kłodzińska A., Grzęzawisko, Wydawnictwo Ministerstwa Obrony Narodowej, Warszawa 1981.

Kłodzińska A., Malwina przegrała milion, Wydawnictwo Ministerstwa Obrony Narodowej, Warszawa 1984.

Kłodzińska A., W pogardzie prawa, Wydawnictwo Ministerstwa Obrony Narodowej, Warszawa 1983.

Kłodzińska A., Zdrajca, Wydawnictwo Ministerstwa Obrony Narodowej, Warszawa 1984.

Koprowski J., Maskotka, Iskry, Warszawa 1978.

Korkozowicz K., Biały płaszcz w brązowa kratę, Krajowa Agencja Wydawnicza, Warszawa 1975.

Kostecki T., Zaułek mroków, Iskry, Warszawa 1956.

Łoziński J., Sceny myśliwskie z Dolnego Śląska, Państwowy Instytut Wydawniczy, Warszawa 1985.

Morena A. [właśc. A. Wydrzyński], Czas zatrzymuje się dla umarłych, Iskry, Warszawa 1969.

Nawrocka-Dońska B., Doński R., Akcja „Chirurg”, Iskry, Warszawa 1968.

Parfiniewicz J., U progu nicości, Wydawnictwo Ministerstwa Obrony Narodowej, Warszawa 1983.

Safjan Z., Włamywacze, Iskry, Warszawa 1971.

Sławek G.R., W matni, Wydawnictwo Ministerstwa Obrony Narodowej, Warszawa 1986.

Szczerba R., Alibi, Iskry, Warszawa 1973.

Szczerba R., Szakale, Czytelnik, Warszawa 1959.

Zbych A. [właśc. A. Szypulski, Z. Safjan], Bardzo dużo pajacyków, Iskry, Warszawa 1968.

Ziemski K., Barwy strachu, Wydawnictwo Ministerstwa Obrony Narodowej, Warszawa 1981.

\section{Opracowania}

[b.a.], Strzały na Placu św. Piotra, „Rzeczywistość” 1981, nr 1, s. 1.

Barańczak S., Poetyka polskiej powieści kryminalnej, „Teksty” 1973, nr 6, s. 63-82.

Barańczak S., W kręu powieści: nadludzie w niebieskich mundurach, [w:] idem, Czytelnik ubezwłasnowolniony. Perswazja w masowej kulturze literackiej PRL, Libella, Paryż 1983, s. 96132.

Barthes R., System mody, przeł. M. Falski, Wydawnictwo Uniwersytetu Jagiellońskiego, Kraków 2005.

Bielicki T., Kto zabit Ritę Croy?, „Dziś i Jutro. Katolicki Tygodnik Społeczny” 1954, nr 37, s. 8.

Bieńkowska D., Zapożyczenia z języka literackiego w gwarach okolic Betchatowa, „Acta Universitatis Lodzendzis. Folia Linguistica" 1987, nr 16, s. 221-236.

Blackman C., 100 lat mody męskiej, przeł. E. Romkowska, Arkady, Warszawa, 2015.

Bojko Ł., Geneza i działalność Resortu Bezpieczeństwa i Urzędu Bezpieczeństwa Polski Ludowej w latach 1944-1945, [w:] „Polska Ludowa” 1944-1989 - wybrane problemy historii politycznej i społecznej, red. D. Litwin-Lewandowska, K. Bałękowski, Wydawnictwo Naukowe „Tygiel”, Lublin 2016, s. 17-36. 
Brzóstowicz-Klajn M., Od inteligenta do fachowca. O projektowanej przemianie inteligencji $w$ świecie wykreowanym w socrealistycznej literaturze, [w:] Presja i ekspresja. Zjazd szczeciński i socrealizm, red. D. Dąbrowska, P. Michałowski, Wydawnictwo Naukowe Uniwersytetu Szczecińskiego, Szczecin 2002, s. 167-179.

Dekret z dnia 20 lipca 1954 roku o Milicji Obywatelskiej, Dz.U. z 1954 r. Nr 34, poz. 143, art. 12.

Dudziński R., Między literatura a filmem, miedzy władza a widzem. Miejsce ideologii w serialu ,07 zgłoś się" i jego literackich pierwowzorach, [w:] Wybory popkultury. Relacje kultury popularnej z polityka, ideologia i społeczeństwem, red. K. Kowalczyk, J. Płoszaj, Stowarzyszenie Badaczy Popkultury i Edukacji Popkulturowej „Trickster”, Wrocław 2014, s. 84-112

Gumowska I., Kapica J., Uprzejmy milicjant, Oddział szkolenia KGMO, Warszawa 1964.

Jacobson R., Upadek filmu?, przeł. Cz. Dondziłło, [w:] Estetyka i film, red. A. Helman, Wydawnictwa Artystyczne i Filmowe, Warszawa 1972, s. 93-102.

Jastrzębski J., „Ewa wzywa 07” - 07 nie odpowiada, [w:] idem, Czas relaksu. O literaturze masowej i jej okolicach, Ossolineum, Wrocław 1982, s. 184-199.

Kargól M., Szarość, brud, brzydota. Niedbalstwo jako (nie)zamierzona forma komunikacji, „Fragile" 2014, nr 1, s. 95-99.

Kelera J., Odwilz w dramacie 1954-1956, „Dialog” 1989, nr 6, s. 97-106.

Kowalska K., Łakoma A., Szymoniuk B., Wizerunek biznesowy, Politechnika Lubelska, Lublin 2011.

Kronika PRL, t. 16. Moda, Edipresse Polska, Warszawa 2015.

Kwiatek P.W., Zagadki bez niewiadomych, czyli kto i dlaczego zamordowat polska powieść kryminalna, Wydawnictwo „Piekarska 221b”, Warszawa 2007.

Majer P., Milicja Obywatelska 1944-1957, Wydawnictwo Uniwersytetu Warmińsko-Mazurskiego, Olsztyn 2004.

Majer P., Milicja Obywatelska w systemie organów władzy PRL, Wydawnictwo Adam Marszałek, Torun 2003.

Majer P., Milicyjna agentura 1944-1957, „Dzieje Najnowsze” 2005, nr 1, s. 47-68.

Majer P., Model Milicji Obywatelskiej realizowany w latach 1944-1990, [w:] Policja w Polsce. Stan obecny i perspektywy, t. 1, red. A. Szymaniak, W. Ciepiela, Wydawnictwo Naukowe Instytutu Nauk Politycznych i Dziennikarstwa UAM, Poznań 2007, s. 27-50.

Majer P., Zacieśnianie więzów. Milicja Obywatelska a aparat bezpieczeństwa w latach 1944-1949, [w:] System represji stalinowskich w Polsce 1944-1956. Represje w Marynarce Wojennej, red. I. Hałagida, IPN, Gdańsk 2003, s. 31-44.

Mudyń K., $O$ dwóch sposobach metaforyzacji świata. Pars pro toto czy intra pro extra?, „Albo Albo" 2008, nr 1, s. 101-116.

Piotrowski D, Struktura organizacyjna Policji po 1989 r., „Security, Economy \& Law” 2015, nr 7, s. $39-52$.

Podemski K., Obrazy i wizje spoleczeństwa polskiego w prasie krajowej w 1981 roku, Wydawnictwo Naukowe UAM, Poznań 2008.

Roetzel B., Gentleman: moda ponadczasowa, przeł. J. Pokora, M. Rulski-Bożek, S. Ratajczyk, Firma Księgarska Olesiejuk, Ożarów Mazowiecki 2009.

Rokicki K., Chrzest bojowy ZOMO, „Pamięć i Sprawiedliwość” 2007, nr 6/1 (11), s. 421-431.

Rozporządzenie Ministra Bezpieczeństwa Publicznego z dnia 29 września 1948 roku o umundurowaniu i oznakach służbowych funkcjonariuszów Milicji Obywatelskiej, Dz.U. z 1948 r. Nr 47, poz. 357, z późn. zm.

Siewierski J., Powieść kryminalna, KAW, Warszawa 1979.

Skotarczak D., Pierwsze i drugie życie powieści milicyjnej, [w:] Popkomunizm. Doświadczenie komunizmu a kultura popularna, red. M. Bogusławska, Z. Grębecka, Libron, Kraków 2010, s. $101-110$. 
Sobczak B., Retoryka a niejęzykowe środki komunikacji, „Poznańskie Studia Polonistyczne. Seria Językoznawcza" 15, 2009, s. 57-76.

Ster, Powieść kryminalna i matpie zwierciadło, „Słowo Powszechne” 1957, nr 178, s. 4.

Surówka B., Maty przeglą , kryminalistyczny”, „Panorama” 1956, nr 36, s. 12-13.

Szymański J., Nauki pomocnicze historii, Wydawnictwo Naukowe PWN, Warszawa 1983.

Tseëlon E., Modele przejścia: o przeobrażeniach kulturowej roli modelki, [w:] Moda: model(ka) i czytelnicy. O ikonicznych reprezentacjach w kulturze, red. M. Gołąb, N. Schiller, Wydawnictwo Uniwersytetu Łódzkiego, Łódź 2015, s. 16-25.

Ustawa z dnia 31 lipca 1985 roku o służbie funkcjonariuszy Służby Bezpieczeństwa i Milicji Obywatelskiej Polskiej Rzeczypospolitej Ludowej, Dz.U. z 1985 r. Nr 38, poz. 181.

Williams D., Sołtysiak G., Modny PRL, Wydawnictwo Znak, Warszawa 2016.

Young M.D., Introduction to the Transaction Edition, [w:] idem, The Rise of the Meritocracy, Transaction Publishers, New Brunswick-London 2008, s. XI-XVII.

Zakrzewski M., Trucizna, sztylet, kula, „Życie Literackie” 1956, nr 9, s. 7.

Zarządzenie $\mathrm{nr}$ 42/55 MSW w sprawie wprowadzenia przepisów ubiorczych dla funkcjonariuszy MO i kursantów szkół MO oraz w sprawie określenia terminu i kolejności wprowadzania nowego koloru umundurowania MO obowiązujące od 1 maja 1955 roku do dnia 29 października 1969 roku [L.dz. AB-741/55].

Zarządzenie nr 55/74 MSW w sprawie przepisów ubiorczych funkcjonariuszy Milicji Obywatelskiej obowiązujące od dnia podpisania, to jest 30 lipca 1974 roku do dnia 9 sierpnia 1990 roku [L.dz. PMŻ-453/74].

\section{Źródła internetowe}

Kiereński J., Grzęzawisko - Czyli Dyrektory to Potwory..., [rec. A. Kłodzińska, Grzęzawisko], „Klub Mord”, http://www.archiwum.klubmord.com/Recenzje/klodzinska-anna-grzezawisko-jk.html (dostęp: 20.12.2018).

\section{The trendy "Mister Law". Costumes of the Citizen's Militia (MO) officials in the Polish militia literature of 1956-1989}

Summary

Creation of the militiaman - treated as a representative figure for the specific type of literary character typical for militia literature - was functionalised in such a way to present militiamen as heroes on and off duty. This is why they used their inconspicuous appearance as a "weapon" for fighting against criminals. The worldly gentleman allowed the creation of the image of an "ideal militiaman". These two strategies were supposed to evoke trust towards the investigative and policing organs, overused during the Stalinist period. In that way, "the supermen in blue uniforms" (a term created by Stanisław Barańczak) (re)gained their humanity becoming appealing to the readers; all in compliance with the ideological premises, however, due to different reasons than the national policymakers wished.

Thus, the reconfigurations of the image of the militia official in "neo-militia literature", having a demystifying tone, show to what extent the image created by the writers of militia literature remained artistically prominent. However, nowadays not only this demystifying notion, but also militia literature 
is regaining its popularity, the proof being the activity of its readers on the internet. The reason why these stories - very often full of propaganda — are interesting for readers may be their documentary values. It seems, however, that it is especially the depiction of the heroes perceived not as representatives of the policy, but as single units coping with the everyday struggles of living in the PRL (The Polish People's Republic), that has the greatest influence on the popularity of this genre. 